\title{
Microbiological community structure on logs used for groynes in a riverbank system
}

\author{
Nanako Ishiyama' ${ }^{1}$ Sakae Horisawa ${ }^{1 *} \mathbb{D}$, Tadashi Hara² ${ }^{2}$ Makoto Yoshida ${ }^{3}$ and Ikuo Momohara ${ }^{4}$
}

\begin{abstract}
It is important for civil engineering applications to investigate resistance to wood decay in aqueous environments. DNA from microorganisms inhabiting logs (groynes) that had been used for about 15 years as a water control system to prevent riverbank erosion was extracted and the microbial community structure was examined. DNA was extracted from specimens in four sections, above and under the water, under the ground and from the bottom parts of the logs that were pulled out from the river. Then, barcode sequences for the detection of fungi and bacteria were amplified from each DNA sample by polymerase chain reaction. Microbes were identified from the nucleotide sequences, and the relationships between microbes and environmental conditions were discussed. The wood in the section above the water was significantly decayed, while slight decay and strength loss were observed in the other sections. The white-rot basidiomycete Xeromphalina sp. was detected in the section above the water, suggesting that this fungal species was responsible for the significant decay of the logs in this study. Wood in the sections under the water and under the ground including the bottom of the logs was not decayed even though the fungus was detected in all sections of the logs, suggesting that Xeromphalina sp. could not degrade the wood in the water and underground where the oxygen supply was limited.
\end{abstract}

Keywords: Groyne, Water system log, Wood-rot fungi, Bacteria, Wood decay

\section{Introduction}

Wood is a renewable material produced by plants through carbon fixation. The use of wood has positive ripple effects because it is carbon neutral, functions as a carbon sink, can revitalize forest industries and help prevent landslide disasters through proper forest management. In recent years, therefore, wood has been re-evaluated as a material for building and civil engineering [1, 2]. Examples of wood utilization for civil engineering applications include ground improvement, loggers, wooden fences, erosion control dams, river improvement, water control, and guardrails, in which construction methods taking advantage of the strength, viscoelasticity and environmental affinity of wood have been developed [3-7]. The long-term use of wood as

\footnotetext{
*Correspondence: horisawa.sakae@kochi-tech.ac.jp

${ }^{1}$ Graduate School of Engineering, Kochi University of Technology, Kami, Kochi 782-8502, Japan

Full list of author information is available at the end of the article
}

a civil engineering material is thought to contribute to the reduction of carbon dioxide emission and the mitigation of climate change from the perspective of carbon sinks and storage because civil engineering consumes a large amount of wood $[5,8-10]$. To optimize the use of wood in civil engineering, it is necessary to provide information about durability because wood is deteriorated by various environmental factors including biological and non-biological reactions.

A river groyne is a civil engineering structure that is used for the control of water flow by installing huge stones and concrete blocks in the bank of the river. The structure enables the control of riverbank erosion at a bend in the river and protects the bank from the action of running water [11-14]. In addition to stones and concrete blocks, water control technology using logs has been also used in many parts of the world. The wood-based river groyne system has some advantages from the viewpoints of environmental friendliness and landscape harmony, but the log piles used for this 
purpose can be attacked by microorganisms when they are used over long periods. Therefore, it is important to understand the biodegradation mechanism of log piles with long-term use as well as the effects of environmental factors such as water, temperature, oxygen, light, and $\mathrm{pH}$ on the properties of log piles [15]. There is currently limited knowledge of the biodegradation mechanism of log piles.

In this study, three Japanese cedar (Cryptomeria japonica) logs that had been installed as a water control system in the Kokubu River in Kochi Prefecture, Japan, for about 10 years were collected, and the microbial degradation of the logs was investigated. The logs had been driven into the riverbed to prevent erosion by water and spanned the area from the air to the ground through the water. Therefore, they were considered suitable for a comparative study of microbial degradation in different environments. The strength of the same logs was previously evaluated by Hara et al., showing that the wood was sound below the water level $[16,17]$. In the present study, DNA-based techniques were applied to these logs to detect wood degrading microbes present in the different environments. The method using genetic analysis has advantages over conventional methods in terms of the short time required to obtain results, reproducibility, and objectivity [18, 19]. Furthermore, the extraction of DNA directly from the wood samples enables the detection of fungi that are difficult to culture and the detection of microbes present at low abundance [20-23]. We show here the microbiological community composition on the logs in different environments and discuss the relationship between the microbiological communities and residual strength of the logs.

\section{Materials and methods}

\section{Sample collection and measurement of Pilodyn} penetration depth

Three C. japonica logs used as river groynes were collected in Dec. 2017. The logs were installed on the outside of a bend in the Kokubu River (N33.5883, E133.6059) in Kochi City, Kochi Prefecture (Fig. 1); this area was damaged by heavy rains in Sep. 1998 and the water system using the logs was constructed as a part of a river restoration project during 1998-2004. The site where logs were installed had almost no slope, and the water level was almost constant throughout the year because there was a weir just downstream. Logs No. 1, No. 2, and No. 3 were about $430 \mathrm{~cm}, 325 \mathrm{~cm}$, and $435 \mathrm{~cm}$ long, respectively, and all were approximately $20 \mathrm{~cm}$ in diameter. The bottom end of the logs had been cut into a pencil shape with a length of $30 \mathrm{~cm}$ and some parts of the bark remained on the logs when they were pulled out (Fig. 2). The logs were promptly evaluated for log surface soundness using a Pilodyn 6J-Forest with pin diameter of $2.5 \mathrm{~mm}$ and measurement range of $0-40 \mathrm{~mm}$ (Proceq, Schwerzenbach, Switzerland) [16]. Pilodyn shots on each of four aspects were taken at $5 \mathrm{~cm}$ intervals of the longitudinal direction. The logs were then divided into the aerial, aqueous, and underground sections, and the pencil-shaped bottom tip, and samples for microbial analysis were cut from sapwood of the logs (Fig. 2).

\section{Observation of split sections of wood using a scanning electron microscope}

The dried wood blocks were cut into small cubes $\left(1 \mathrm{~cm}^{3}\right)$ and then affixed to aluminum stubs with electronconductive carbon tape. They were coated with gold using a JFC 1200 Fine Coater (JEOL, Tokyo, Japan). The

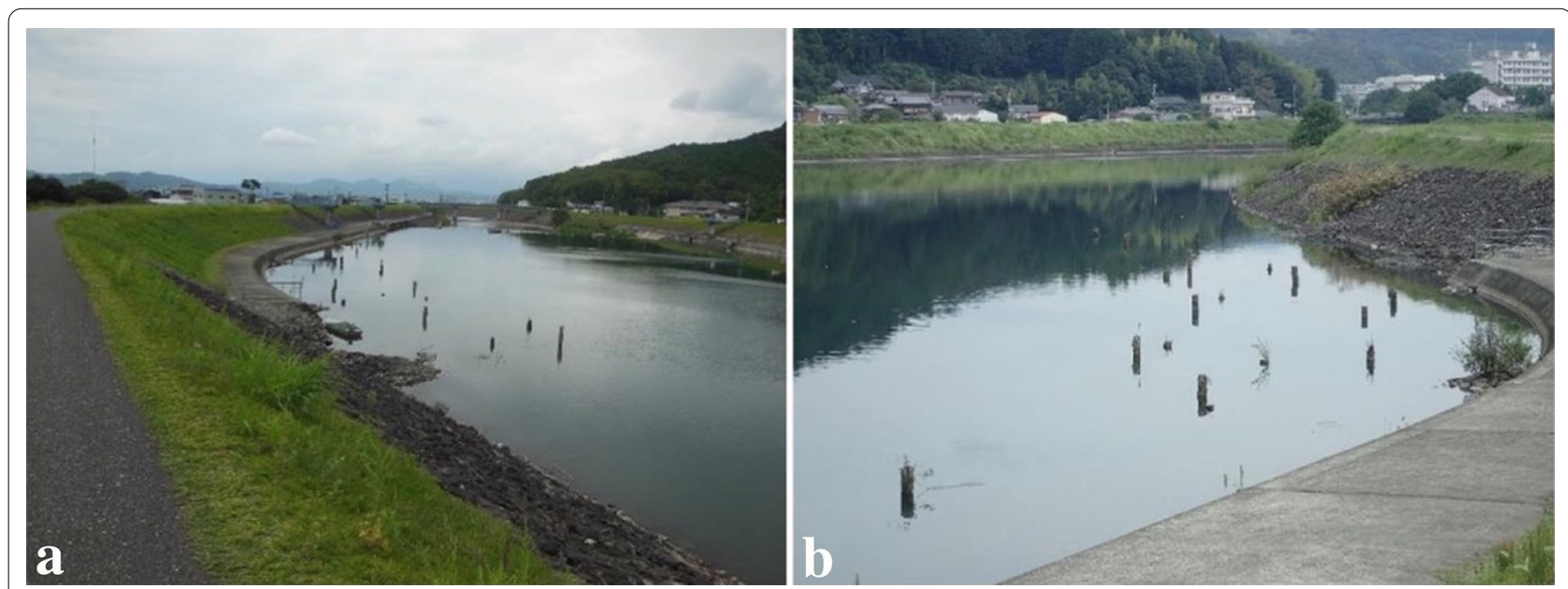

Fig. 1 A full view of river groynes using logs in the Kokubu River: a from the upstream side, $\mathbf{b}$ from the downstream side 


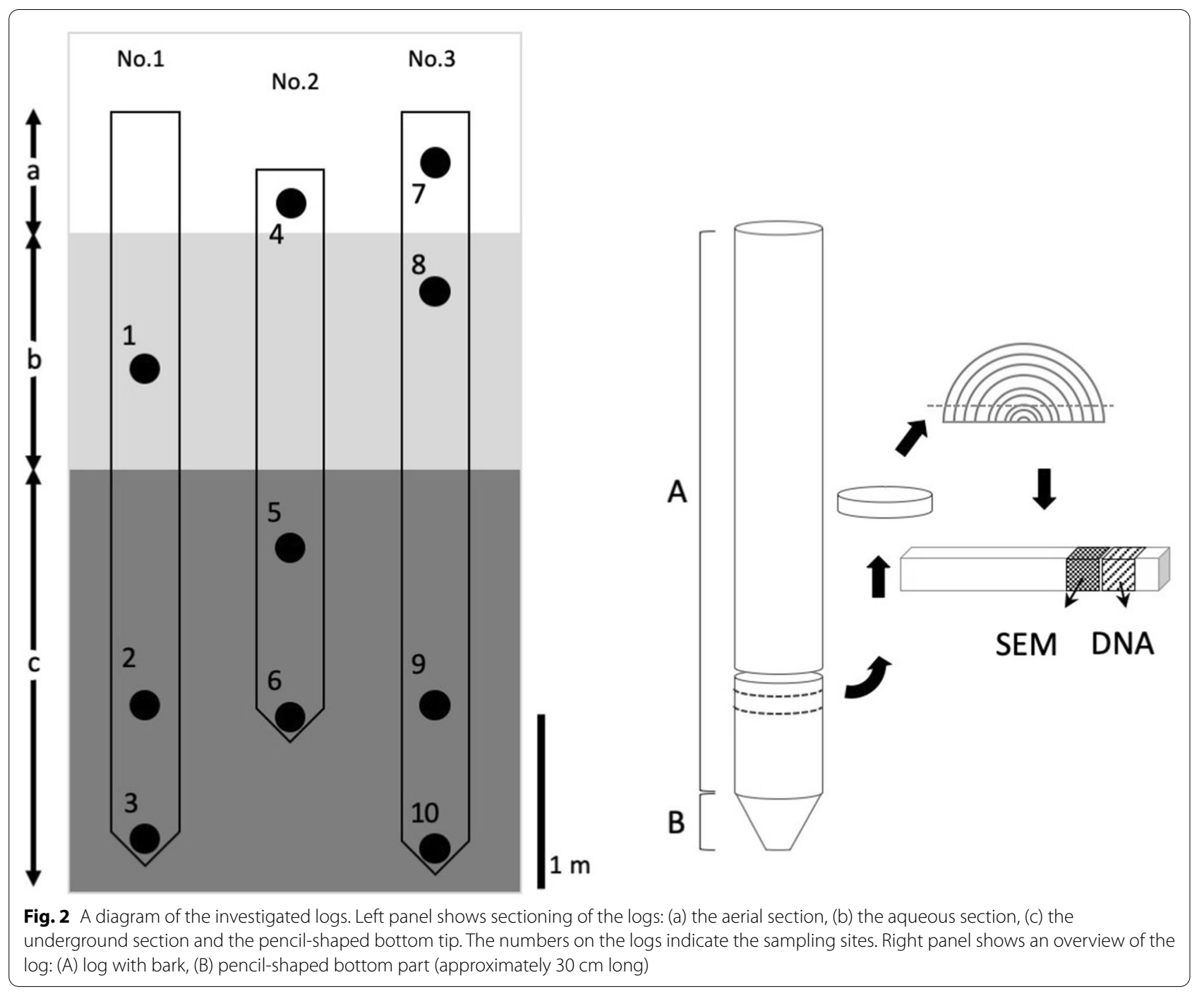

degradation of the cell wall and the microbes around them were observed with a Hitachi S-3000N scanning electron microscope (SEM; Hitachi High Technologies, Tokyo, Japan) at an accelerating voltage of $15 \mathrm{kV}$ and at a working distance of $30 \mathrm{~mm}$.

\section{DNA extraction from wood samples}

After removing the surface of each sample to avoid microbial contamination, the inside of the sample was cut into small pieces. These operations were conducted with a knife sterilized with ethanol. The small pieces were ground into a powder using a Qiagen Tissue Lyser (Qiagen, Venlo, Netherlands) at $25 \mathrm{~Hz}$. DNA extraction was performed using ISOPLANT II (Nippon Gene, Tokyo, Japan) with a modification of the manufacturer's protocol. Approximately $0.1 \mathrm{~g}$ of wood powder was placed in a $2 \mathrm{~mL}$ polypropylene tube with one $7-\mathrm{mm}$ zirconia bead and $1 \mathrm{mg}$ of $0.2-\mathrm{mm}$ zirconia beads, and then ground into powder using the tissue lyser at $25 \mathrm{~Hz}$ for $2 \mathrm{~min} .1000 \mu \mathrm{L}$ of Wash buffer from the ISOPLANT II kit was added to the tube and mixed using the tissue lyser for $2 \mathrm{~min}$. After centrifugation at $15,000 \mathrm{rpm}$ for $10 \mathrm{~min}$, the supernatant was discarded and the purified wood powder was collected. After that, genomic DNA was extracted in accordance with the ISOPLANT II instructions. If the DNA could not be extracted by the above method, it was extracted using the Qiagen Genomic DNA (20G) kit with a modified protocol. Approximately $0.1 \mathrm{~g}$ of wood powder was placed in a $5 \mathrm{~mL}$ polypropylene tube, then $1.5 \mathrm{~mL}$ of Tris-EDTA buffer was added and mixed to wash the wood powder. After centrifuging at $15,000 \mathrm{rpm}$ for $10 \mathrm{~min}$ and discarding the supernatant, $1 \mathrm{~mL}$ of TrisEDTA was added to wash the wood powder again. 
After that, genomic DNA was extracted in accordance with the manufacturer's protocol.

\section{Analysis of microbial communities}

Polymerase chain reaction (PCR) was conducted to obtain DNA fragments of the internal transcribed spacer (ITS) region of the rRNA gene for detection of fungi and the V3-V4 region of the 16s rRNA gene for bacteria. MightyAmp DNA Polymerase Ver.2 (Takara Bio, Kusatsu, Japan) was used for PCR. Nested PCR was performed to increase the yield of amplicons using the primer pairs as follows; NS7 and NL4 primer pairs for the first round PCR, and ITS1 and ITS4 primer pairs for the second round PCR to amplify the ITS region [24]; $27 \mathrm{~F}$ and $1492 \mathrm{R}$ primer pairs for the first round PCR [25], and $341 \mathrm{~F}$ and $805 \mathrm{R}$ primer pairs for the second round PCR to amplify the V3-V4 region $[26,27]$. PCR amplicons were purified using the Nucleospin Gel and PCR clean-up kit (Takara Bio) in accordance with the manufacturer's protocol. A clone library analysis was conducted separately for each section in each log using the Mighty TA-cloning kit (Takara Bio). About 20 clones per section of sample log were sequenced with the Sanger method for species identification. The sequences obtained were compared with the GenBank/DDBJ/EMBL database by BLAST search and species were identified by comparison with highly homologous sequences.

\section{Results}

Evaluation of soundness of the logs and SEM observation of the cell wall surface

The wood in the aerial section of the logs used as river groynes (Fig. 2A) was significantly deteriorated almost to collapse by touching. A characteristic white pocket rot was observed on the inside part of the aerial section of the logs (Fig. 3b). In the other sections, no deterioration was detected visually and some of the bark remained on the log surface. The cross section of the logs showed that the outer side of the log was slightly discolored to gray, but the color of the heartwood and sapwood inside the log was almost unchanged (Fig. 3a). The Pilodyn penetration depth of all sections except for the aerial section was between 20 and $24 \mathrm{~mm}$ in the No. 1 and 2 logs, and $24-27 \mathrm{~mm}$ in the No. $3 \log$ (Table 1). The average moisture content in the aqueous and underground sections was $171 \%$ and $180 \%$, respectively [16]. A comparison between the penetration depth of this study and the values reported in previous studies suggested that the cedar logs collected in this study were almost sound [28, 29]. The split surfaces of the log were observed by SEM to investigate the microbial presence and microstructure inside the $\log$ (Fig. 4). On the inside of the severely deteriorated wood in the aerial section, thinned cell walls were observed, probably because of degradation by wood-rotting fungi; however, no mycelia or other microbial structures were observed (Fig. 4a). Around a boundary region between the aerial and aqueous sections, little degradation of cell walls was observed, although good growth

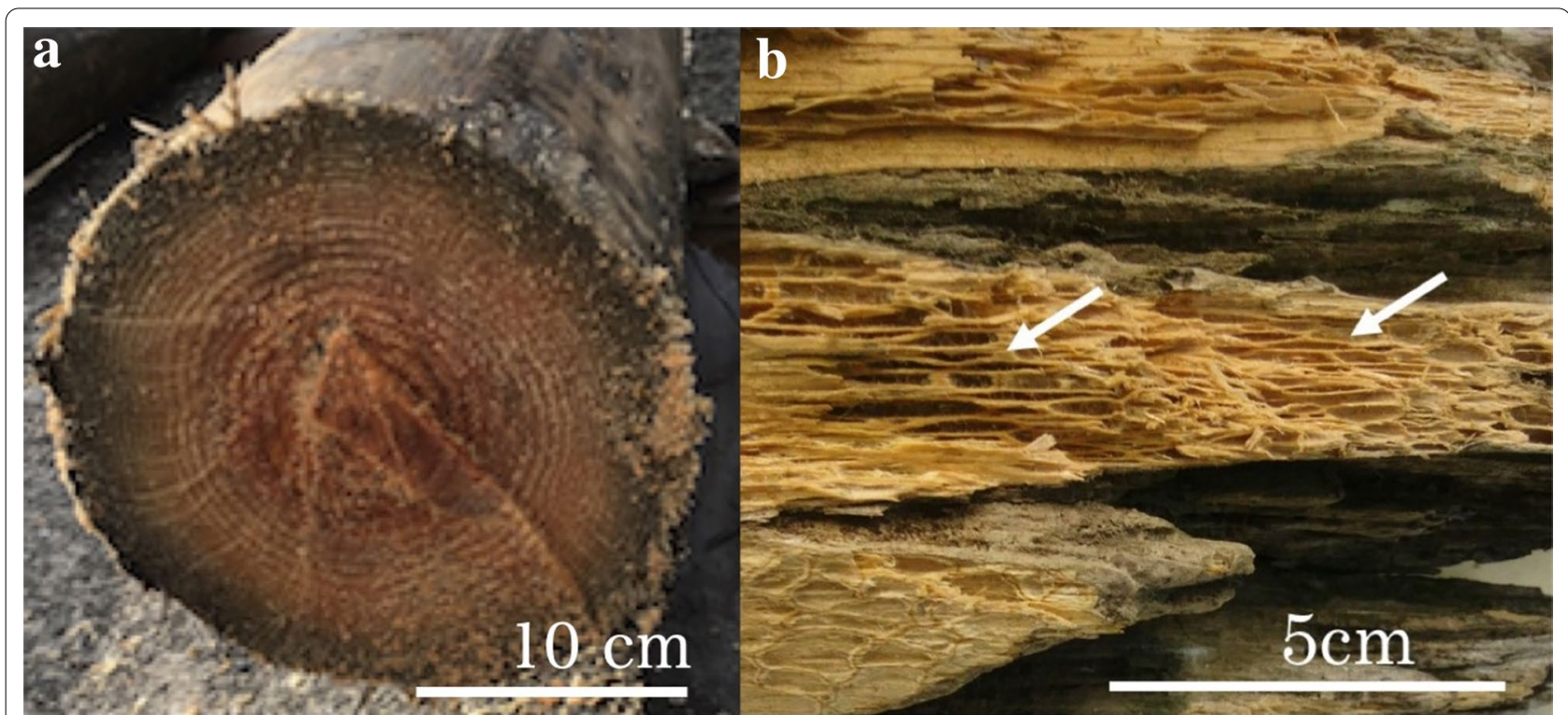

Fig. 3 Appearance of the cross section of the No. 3 log. a The surface of the cross section just after the log was pulled out showed that the original color of the heartwood was maintained. $\mathbf{b}$ A honeycomb-like pocket rotting (white arrows) was found in the deteriorated part in the aerial section 
Table 1 The average Pilodyn penetration depth in each section $(\mathrm{mm})$

\begin{tabular}{|c|c|c|c|c|c|c|}
\hline & \multicolumn{2}{|l|}{ No. 1} & \multicolumn{2}{|l|}{ No. 2} & \multicolumn{2}{|c|}{ No. 3} \\
\hline & Avg. & SD & Avg. & SD & Avg. & SD \\
\hline Aerial section & 31.8 & 4.9 & 21.3 & 1.4 & 38.0 & 2.3 \\
\hline Aqueous section & 23.6 & 1.1 & 21.8 & 1.0 & 26.8 & 1.5 \\
\hline Underground section & 22.5 & 1.0 & 19.5 & 0.5 & 25.4 & 1.1 \\
\hline Pencil-shaped bottom section & 23.8 & 1.4 & 24.0 & 1.6 & 24.1 & 1.6 \\
\hline
\end{tabular}

$S D$ standard deviation

of mycelium was observed (Fig. 4b). In the aqueous and underground sections, there was little wood degradation, and spherical cell-like structures were found on the lumen of the tracheids (Fig. 4c).

\section{Identification of microbes and analysis of microbial communities}

Almost no amplicon was obtained when single round PCR was performed with the extracted DNA as a template. Therefore, nested PCR was performed to obtain enough amplicon for sequence-based identification of microorganisms, although PCR amplicons were still not obtained for some samples. The obtained amplicons were sub-cloned for sequencing analysis followed by BLAST search as described in the materials and methods section. Bacterial diversities were low in both the aerial and aqueous sections, but were higher in the underground and pencil-shaped sections. Pseudomonas spp., which was detected in the pencil-shaped sections in the present study (Table 2), have been reported to be associated with wood degradation [30, 31]. In addition, Dongia sp. was detected in the aerial and underground sections, Bradyrhizobium sp. was detected in the aerial and aqueous sections, and Chloroflexi spp., Syntrophomonas spp. and Firmicutes sp. were detected in the pencil-shaped sections (Table 2). There was low genus-level diversity of fungal communities in all sections (Table 2). Characteristically, the white-rot fungus Xeromphalina spp. was widely detected from the wood in the aerial, aqueous and underground sections of all logs. In addition, known wood decay fungi including Byssomerulius corium, Xylodon paradoxus and Xylodon sp. were detected. The ITS region amplicons of plants, not cedar, were detected in all sections except for the pencil-shaped bottom section. These were thought to come from plant tissue or pollen in the water that might have been attached to the logs, suggesting that the amount of microbial DNA in the logs was very small. The reason why no microbial DNA was detected by PCR in the significantly degraded wood in the aerial section even though the pocket rot-like appearance was observed, was because the microbial DNA had been degraded or washed away by sunlight irradiation and water flow, respectively.

\section{Discussion}

The logs employed as river groynes for about 15 years showed little or no deterioration except for the aerial section. This was supported by the results of the Pilodyn penetration test. Hara et al. evaluated the Young's modulus of the same logs by vertical compressive strength and vibration methods and reported that the strength of these logs remained as strong as that of sound cedar wood [16]. It is empirically known that wood is barely degraded in environments such as in water or underground because of the lack of oxygen supply, which was confirmed by the soundness of logs in this study. The thinned cell walls observed in the significantly degraded logs in the aerial section was thought to be caused by sunlight and biodegradation. The pocket rot-like appearance of the logs in the aerial section indicated that wood-rotting fungi were involved in this wood deterioration. The white-rot fungus Xeromphalina sp. was detected and identified by DNA sequencing analysis in the aerial, aqueous, and underground sections. The genus Xeromphalina was reported to be found on cedar wood [32]. SEM observations showed that the cell walls in the air section were thinner due to degradation, but no degradation was observed in the water part. These facts suggest that members of this fungal genus can degrade wood in the presence of oxygen, as in the aerial section, but might not be capable of wood decay under an oxygen-deficient environment. Wood, used in underwater construction work such as water groynes, or in underground construction such as a Log Piling Method for Liquefaction Mitigation and Carbon Stock (LP-LiC method) [33-35], is considered to have a long service life because the degradation activity of wood-rotting fungi that use oxygen is almost completely stopped and the deterioration in strength progresses very slowly [36]. In this study, in a stable underwater environment with small fluctuations in water level, almost no wood deterioration by fungi occurred.

For wood degradation in the environment with low oxygen supply, such as in the water or below the 

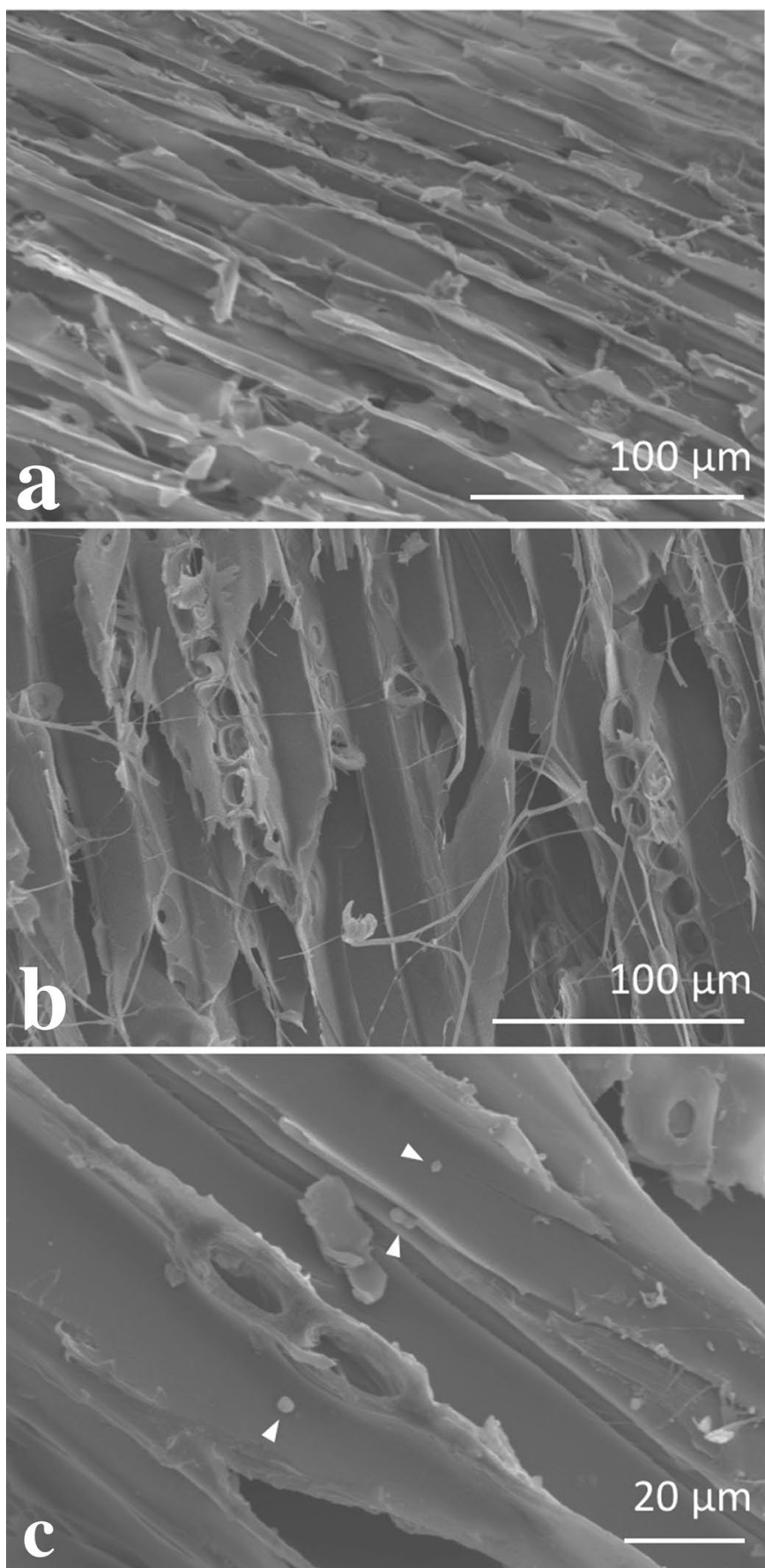

Fig. 4 Scanning electron microscopy observation of cell walls of wood. a Thinned cell walls in the aerial section; $\mathbf{b}$ spreading mycelia around wood tissue in a relatively shallow part of the aqueous section; c wood tissue in the aqueous section, where a few spherical cells were observed (arrowheads)

groundwater level, anaerobic bacteria might be important. In this study, a rich diversity of bacteria was detected in the pencil-shaped sections under the ground. In the case of logs with bark as in this study, bacteria are thought to have entered through the pencil-shaped section where the cross section of wood was exposed as it was reported that bacteria migrate into the wood with water flow [36]. Bacteria, along with the water, are thought to migrate upward with time [37, 38]. Pseudomonas spp. were predominantly detected in the 
Table 2 Bacterial and fungal species identified in the logs

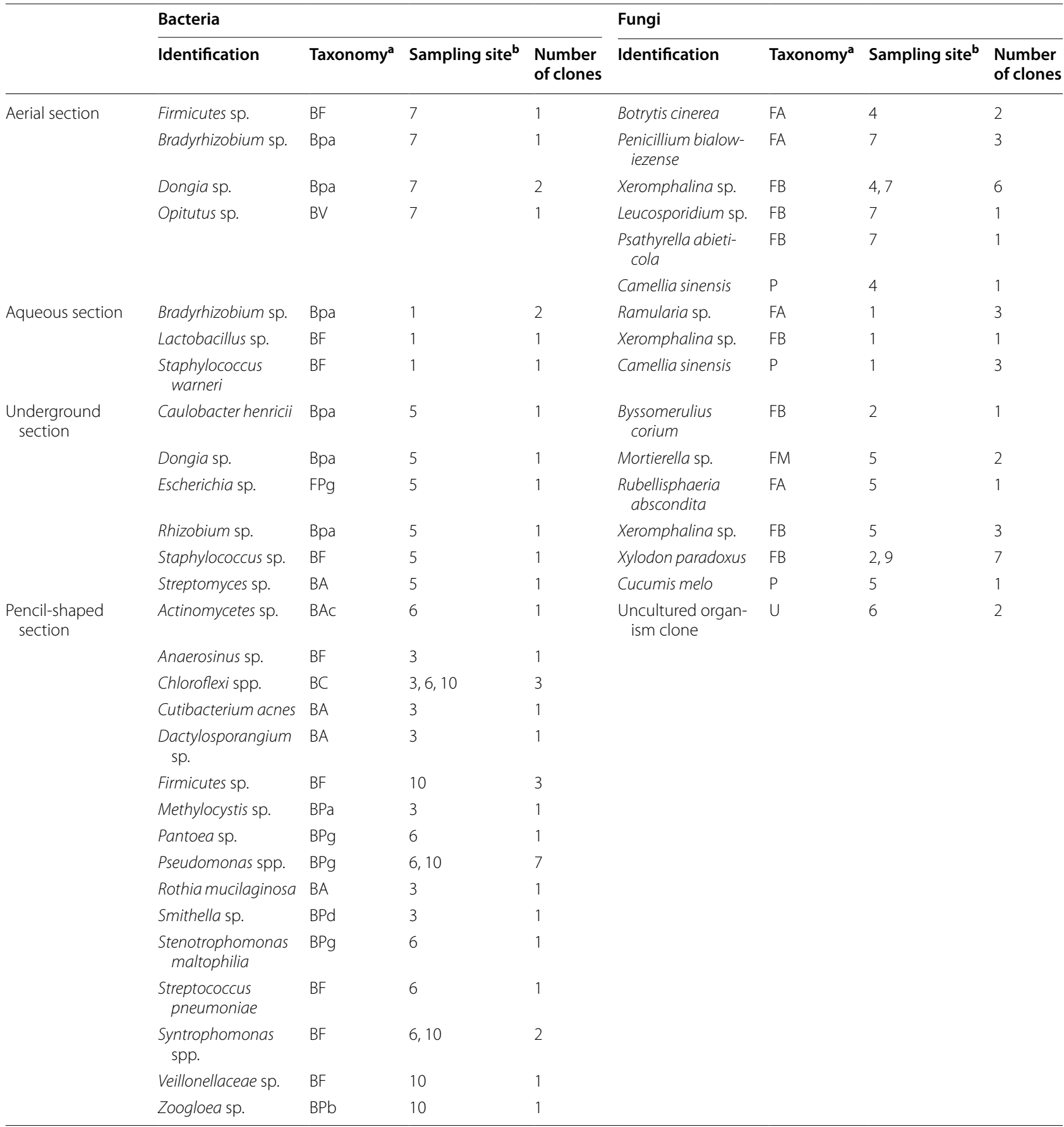

a $B A$ Actinomycetes, $B A C$ Acidobacteria, $B C$ Chloroflexi, $B F$ Firmicutes, $B P a$ Alphaproteobacteria, $B P b$ Betaproteobacteria, $B P g$ Gammaproteobacteria, $B P d$ Deltaproteobacteria, BV Verrucomicrobia, FB Basidiomycota, FM Mucoromycota, $P$ plant, $U$ unidentified

b See Fig. 2

pencil-shaped sections in the logs of the present study. They have been reported to be associated with serious wood degradation over several decades even in water and soil [39-41]. Dongia sp., detected in the aerial and underground sections, is a widespread bacterium in soils and other areas [42], and has been reported to increase in abundance in soil contaminated with aromatic compounds [43]; however, its function in wood degradation is not yet well understood. Other bacteria were detected, such as the root-nodulating bacterium Bradyrhizobium 
sp., the photosynthetic bacterium Chloroflexi spp., and anaerobic bacteria Syntrophomonas spp. and Firmicutes sp., but their role in wood degradation is unknown. SEM observation of the wood tissue in the water section showed the cell wall was almost sound and there were little bacteria on them, suggesting that bacterial deterioration was hardly progressed. The present study showed that there are few concerns around using wood as a civil construction material in water or underground over a 10 -year period, however, further investigation is needed to understand the longer-term effects of fungal and bacterial degradation under anaerobic conditions.

\section{Conclusions}

In this study, the following conclusions were drawn from the investigation of river groyne logs that had been installed for about 10 years:

- The wood in the aerial section of the logs was severely degraded by white-rot fungi.

- White-rot fungi that degraded wood in the aerial section grew into the wood of the aqueous and underground sections.

- In the aqueous and underground sections, there was no active wood degradation by white-rot fungi.

- As a result, the residual strength of wood decreased only in the aerial section, and the effects of microbes were negligible for $10-15$ years in the water and underground. However, the degradation of wood in the outdoor environment can be greatly influenced by the surrounding environment and the microbial species present, with further study of other cases required.

\section{Abbreviations}

PCR: Polymerase chain reaction; SEM: Scanning electron microscopy; $16 \mathrm{~s}$ rDNA: 16S ribosomal RNA; ITS: Internal transcribed spacer.

\section{Acknowledgements}

The authors acknowledge the support from the River Division of the Civil Engineering Department of Kochi Prefecture for recovering the logs. We would like to thank Dr. Kaori Mimura of Sumitomo Forestry and Hara Laboratory of Kochi University for their cooperation in sample collection. We thank Catherine Dandie, Ph.D., from Edanz Group (https://en-author-services.edanzgroup.com/ ac) for editing a draft of this manuscript.

\section{Authors' contributions}

$\mathrm{NI}, \mathrm{SH}, \mathrm{TH}$, and MY performed most of the experiments. SH, TH, MY, and IM designed the study and interpreted the data. $\mathrm{NI}, \mathrm{SH}, \mathrm{TH}$, and IM wrote the manuscript. SH and $\mathrm{TH}$ managed the project. All authors read and approved the final manuscript.

\section{Funding}

This work was supported by JSPS KAKENHI Grant Number JP19k06170.

\section{Availability of data and materials}

The data sets analyzed during the current study are available from the corresponding author upon reasonable request.

\section{Competing interests}

The authors declare that they have no competing interests.

\section{Author details}

${ }^{1}$ Graduate School of Engineering, Kochi University of Technology, Kami, Kochi 782-8502, Japan. ${ }^{2}$ Natural Sciences Cluster, Research and Education Faculty, Kochi University, Kochi, Kochi 780-8072, Japan. ${ }^{3}$ Department of Environmental and Natural Resource Science, Tokyo University of Agriculture and Technology, Fuchu, Tokyo 183-8509, Japan. ${ }^{4}$ Kansai Research Center, Forestry and Forest Products Research Institute, Forest Research and Management Organization, Kyoto, Kyoto 612-0855, Japan.

Received: 3 November 2020 Accepted: 24 January 2021

Published online: 04 February 2021

\section{References}

1. Kayo C, Noda R (2018) Climate change mitigation potential of wood use in civil engineering in Japan based on life-cycle assessment. Sustainability 10:561-579

2. Ramage M, Burridge $H$, Busse-Wicher M, Fereday $G$, Reynolds T, Shah D, Wu G, Yu L, Fleming P, Densley-Tingley D, Allwood J, Dupree P, Linden P, Scherman O (2017) The wood from the trees: the use of timber in construction. Renew Sustain Energy Rev 68(Part 1):333-359

3. Yoshida M, Miyajima M, Numata A (2013) Application of liquefaction countermeasure technique by log piling for water purification and sewage treatment plant. In: Proceedings of the 6th China-Japan-US trilateral symposium on lifeline earthquake engineering, Chengdu, China, May 28-June 1, 2013

4. Sasaki T, Usuki S, Nakamura N, Nakayama Y (2008) Technical guideline on timber bridge 2005. In: Proceedings of the 10th world conference on timber engineering, Miyazaki, Japan, 2-5 June 2008

5. Noda R, Kayo C, Sasaki T, Takaoku S (2014) Evaluation of $\mathrm{CO}_{2}$ emissions reductions by timber check dams and their economic effectiveness. J Wood Sci 60:461-472

6. Kubojima Y, Sonoda S, Kato H (2018) Application of the vibration method with additional mass to timber guardrail beams. J Wood Sci 64:767-775

7. Imai H, Ikeda Y, Shibata N (2011) Stability evaluation of planted slope considering nature of timber decaying and tree root effect-study on tree planted slope with horizontal step works using logs - technical research report of Hazama Corporation, vol 12, pp 1-6 (in Japanse)

8. Kayo C, Hashimoto S, Numata A, Hamada M (2011) Reductions in greenhouse gas emissions by using wood to protect against soil liquefaction. J Wood Sci 57:234-240

9. Noda R, Kayo C, Yamanouchi M, Shibata N (2015) Life cycle greenhouse gas emission of wooden guardrails: a study in Nagano Prefecture. J Wood Sci 62:181-193

10. Kayo C, Noda R, Sasaki T, Takaoku S (2014) Carbon balance in the life cycle of wood: targeting a timber check dam. J wood sci 61:70-80

11. Simm J, Camilleri A (2007) Construction risk in coastal and river engineering. Water Environ J 15:258-264

12. Aziz P, Kadota A (2018) Experimental study of morphological changes and flow structure around the vegetated groyne. Int J Adv Sci Eng Inf Technol 8:99-107

13. Crossman M, Simm J (2004) Manual on the use of timber in coastal and river engineering. Thomas Telford Publishing, London, pp 155-157

14. Zaid B, Nardone P, Nones M, Gerstgraser C, Koll K (2018) Morphodynamic effects of stone and wooden groynes in a restored river reach. In: Proceedings of the river flow 2018-ninth international conference on fluvial hydraulics, Lyon-Villeurbanne, France, 5-8 September 2018

15. Reinprecht $L$ (2016) Wood deterioration, protection and maintenance. Wiley, West Sussex, pp 28-120

16. Mimura K, Hara T, Hayashi S, Yano K (2018) Long-term durability evaluation of wooden waterworks at Kokubu River, Kochi Prefecture I: outline of construction sites. In: Proceedings of the 73th annual meeting on Japan 
society of civil engineers, Sapporo, Japan, 29-31 August 2018, pp 19-20 (in Japanese)

17. Hara T, Mimura K, Hayashi S, Yano K (2018) Long-term durability evaluation of wooden waterworks at Kokubu River, Kochi Prefecture II: longitudinal compressive strength properties. In: Proceedings of the 73th annual meeting on Japan society of civil engineers, Sapporo, Japan, 29-31 August 2018, pp 21-22 (in Japanese)

18. Suhara H, Maekawa N, Kubahashi T, Kondo R (2005) Specific detection of a basidiomycete, Phlebia brevispora associated with butt rot of Chamaecyparis obtusa, by PCR-based analysis. J Wood Sci 51:83-88

19. Horisawa S, Sakuma Y, Doi S (2013) Identification and species-typing of wood rotting fungi using melting curve analysis. J Wood Sci 59:432-441

20. Pitkäranta $M$, Meklin T, Hyvärinen A, Nevalainen A, Paulin L, Auvinen P, Lignell U, Rintala H (2011) Molecular profiling of fungal communities in moisture damaged buildings before and after remediation-a comparison of culture-dependent and culture-independent methods. BMC Microbiol 11:235

21. Browne H, Forster S, Anonye B, Kumar N, Neville B, Stares M, Goulding D, Lawley T (2016) Culturing of "unculturable" human microbiota reveals novel taxa and extensive sporulation. Nature 533:543-546

22. Horisawa S, Yoshida M, Umezawa K, Wada T, Abe H, Doi S, Samejima M, Momohara I (2017) Diversity and community structure of woodinhabiting fungi found in Japanese wooden houses analyzed by the next-generation sequencing. J Wood Sci 63:369-378

23. Horisawa S, Hamaguchi K (2017) Analysis of fungal diversity and community structure in decayed wood. J For Biomass Util Soc 12:47-52

24. White T, Bruns T, Lee S, Taylor J (1990) Amplification and direct sequencing of fungal ribosomal RNA genes for phylogenetics. In: Innis M, Gelfand D, Sninsky J, White T (eds) PCR protocols: a guide to methods and applications. Academic Press, New York, pp 315-322

25. Lane D (1991) 16S/23S rRNA sequencing. In: Stackebrandt E, Goodfellow $M$ (eds) Nucleic acid techniques in bacterial systematics. Wiley, Chichester, pp 115-175

26. Muyzer G, de Waal EC, Uitterlinden AG (1993) Profiling of complex microbial populations by denaturing gradient gel electrophoresis analysis of polymerase chain reaction-amplified genes coding for 16S rRNA. Appl Environ Microbiol 59:695-700

27. Muyzer G, Teske A, Wirsen CO, Jannasch HW (1995) Phylogenetic relationship of Thiomicrospira species and their identification in deep-sea hydrothermal vent samples by denaturing gradient gel electrophoresis of 16SrDNA fragments. Arch Microbiol 164:165-172

28. Yamada M, Hara T, Mizutani Y, Mimura K, Numata A, Yoshida M, Mori M, Suetsugu D, Noda R, Umezu H (2017) Effects of moisture contents of wood on Pilodyn test values and driver penetration depths. Paper reports on use of wood for civil engineering, vol 16, pp 63-70 (in Japanese)

29. Yamashita K, Okada N, Fujiwara T (2007) Use of the Pilodyn for estimating basic density and its applicability to density-based classifying of Cryptomeria japonica green logs. Mokuzaigakkaishi 53:72-81 (in Japanese)
30. Odier E, Janin G, Monties B (1981) Poplar lignin decomposition by gramnegative aerobic bacteria. Appl Environ Microbiol 41:337-341

31. Kielak A, Scheublin T, Mendes L, van Veen J, Kuramae E (2016) Bacterial community succession in pine-wood decomposition. Front Microbiol 7:231

32. Shinoyama H, Yamazaki T, Suzuki R, Fujii T, Hayashi Y (1996) Isolation of fungi which formed fruiting bodies in litter on the floors of sugi (Cryptomeria japonica) stands and their cultural properties. Mokuzai Gakkaishi 42:901-905 (in Japanese)

33. Numata A, Motoyama H, Kubo H, Yoshida M (2012) Log piling method to mitigate liquefaction damage. In: Proceedings of 15 th world conference on earthquake engineering 2012, Lisbon, Portugal, 24-28 September 2012, pp 17725-17730

34. Riaz S, Numata A, Mimura K, lkeda H, Hori T (2014) The effect of log piling on liquefaction. J JSCE 2:144-158

35. Hara T, Igarashi C, Tezuka D, Horisawa S, Kato H (2020) Evaluation of ground improvement effect and soundness of log piles buried in for an extended period. In: Proceedings of the world conference on timber engineering (WCTE 2016), Vienna, Austria, 22-25 August 2016 (in press)

36. Elam J, Björdal C (2020) A review and case studies of factors affecting the stability of wooden foundation piles in urban environments exposed to construction work. Int Biodeter Biodegr 148:104913. https://doi. org/10.1016/j.ibiod.2020.104913

37. Klaassen R (2008) Bacterial decay in wooden foundation piles_-patterns and causes: a study of historical pile foundations in the Netherlands. Int Biodeter Biodegr 61:45-60

38. Klaassen R (2008) Water flow through wooden foundation piles: a preliminary study. Int Biodeter Biodegr 61:61-68

39. Landy E, Mitchell J, Hotchkiss S, Eaton R (2008) Bacterial diversity associated with archaeological waterlogged wood: ribosomal RNA clone libraries and denaturing gradient gel electrophoresis (DGGE). Int Biodeter Biodegr 61:106-116

40. Palla F, Mancuso F, Billeci N (2013) Multiple approaches to identify bacteria in archaeological waterlogged wood. J Cult Herit 14:e61-e64

41. Johnston S, Boddy L, Weightman A (2016) Bacteria in decomposing wood and their interactions with wood-decay fungi. FEMS Microbiol Ecol 92:fiw179. https://doi.org/10.1093/femsec/fiw179

42. Kim D, Lee H, Kim H, Kim S, Ka J (2016) Dongia soli sp. nov., isolated from soil from Dokdo, Korea. Antonie Van Leeuwenhoek 109:1397-1402

43. Kato H, Mori H, Maruyama F, Toyoda A, Oshima K, Endo R, Fuchu G, Miyakoshi M, Dozono A, Ohtsubo Y, Nagata Y, Hattori M, Fujiyama A, Kurokawa K, Tsuda M (2015) Time-series metagenomic analysis reveals robustness of soil microbiome against chemical disturbance. DNA Res 22:413-424

\section{Publisher's Note}

Springer Nature remains neutral with regard to jurisdictional claims in published maps and institutional affiliations.

\section{Submit your manuscript to a SpringerOpen ${ }^{\circ}$ journal and benefit from:}

- Convenient online submission

- Rigorous peer review

- Open access: articles freely available online

- High visibility within the field

- Retaining the copyright to your article

Submit your next manuscript at $\boldsymbol{\nabla}$ springeropen.com 